\title{
Study of the effect of epidermal overhydration by occlusion, on the skin biomechanical behaviour assessed in vivo with the systems Cutometer ${ }^{\circledR}$, Reviscometer $^{\circledR}$ and CutiScan ${ }^{\circledR}$
}

\author{
Estudo do efeito da sobrehidratação epidérmica por oclusão, sobre o comportamento \\ biomecânico da pele in vivo avaliado com os sistemas Cutometer ${ }^{\circledR}$, Reviscometer $^{\circledR}$ e CutiScan ${ }^{\circledR}$
}

Catarina Rosado $^{1}$, Raquel Barbosa ${ }^{1}$, Raquel Fernando ${ }^{1}$, Filipa Antunes ${ }^{2}$, L Monteiro Rodrigues ${ }^{1,2}$

${ }^{1}$ CBIOS - Universidade Lusófona's Research Center for Biosciences and Health Technologies, Campo Grande 376, 1749024, Lisboa, Portugal

${ }^{2}$ Pharmacological Sciences Department - Universidade de Lisboa, School of Pharmacy, Av. Gama Pinto 1649-003 Lisboa, Portugal.

Email: catarina.rosado@ulusofona.pt

\begin{abstract}
It has long been acknowledged that hydration affects the biomechanical properties of the skin. However, this relationship although widely accepted, has not been entirely demonstrated.

The new testing equipment CutiScan $\mathbb{R}$ CS 100 , recently introduced into the market, corresponds to a new approach on measurement of anisotropy and viscoelasticity, combining mechanical force with imaging in a unique way.

This study aims to study the influence of hydration on the biomechanical properties of skin, as well as to observe the discriminative capacity of the CutiScan ${ }^{\circledR}$ CS 100 when compared with more conventional bioengineering equipment.

To achieve this aim, a sample of 12 healthy volunteers, male and female, ages between 18 and 25 years old (22.8 \pm 1.4$)$ was selected. The study was entirely conducted in the volar forearm, where an occlusive dressing with water and glycerin was applied for 24 hours.

The biomechanical properties of skin were measured, both prior and after the occlusion, with the Reviscometer® RVM 600, Cutometer ${ }^{\circledR}$ MPA 580 and CutiScan ${ }^{\circledR}$ CS 100 (Courage-Khazaka Electronics GmbH) devices.

Results suggest there is an association between hydration and the biomechanical properties of skin. However, this relationship is based in the technology employed and, in our experience, must be further investigated.
\end{abstract}

Keywords: Biomechanical behaviour, human skin in vivo, hydration, CutiScan ${ }^{\circledR}$ CS 100 .

\section{Resumo}

Há muito que se sugere que a hidratação afeta as propriedades biomecânicas da pele in vivo. No entanto, apesar de aceite, esta relação não foi ainda claramente demonstrada com a tecnologia de que dispomos. Recentemente foi introduzido no mercado o Cutiscan ${ }^{\circledR}$ CS 100, utilizando uma nova abordagem de medição da anisotropia e viscoelasticidade, combinando força mecânica e imagem de uma forma única.

Este estudo teve como objetivo estudar a influência da hidratação nas propriedades biomecânicas da pele, bem como observar a capacidade discriminativa deste novo sistema, face a outros equipamentos de utilização mais convencional.

Foi selecionada uma amostra de 12 voluntários, saudáveis, de ambos os sexos, com idades compreendidas entre os 18 e os 25 anos (22,8 $\pm 1,4$ anos). O estudo foi inteiramente conduzido no antebraço ventral, onde foi aplicado um penso oclusivo com água e glicerina durante $24 \mathrm{~h}$. As propriedades biomecânicas da pele foram medidas, antes e após a oclusão, com os aparelhos Reviscometer ${ }^{\circledR}$ RVM 600, Cutometer ${ }^{\circledR}$ MPA 580 e CutiScan ${ }^{\circledR}$ CS 100 (Courage-Khazaka Electronics GmbH)

Os resultados obtidos contribuem para admitir a existência de relação entre a hidratação e as propriedades biomecânicas da pele in vivo, embora essa relação dependa directamente da tecnologia utilizada na medição e que, da nossa experiência, precisa de ser melhor compreendida.

Palavras-Chave: CutiScan ${ }^{\circledR}$ CS 100, Hidratação, Pele , Propriedades biomecânicas; comportamente biomecânico; pele humana in vivo; hidratação; CutiScan ${ }^{\circledR}$ CS 100 


\section{Introduction}

The water content of the stratum corneum (SC) is crucial for the maintenance of skin elasticity, tensile strength, barrier integrity and electrical resistance (1). Despite its lipophilic nature, the SC has the capacity to retain water due to the existence of compact connections between corneocytes, lipid regions in the intercellular space, and the natural moisturizing factor (NMF). The latter is obtained by lysis of filaggrin (2), a complex mixture of amino acids, organic acids, urea, and ions. Its effectiveness lies in the fact that it is largely constituted of pyrrolidinecarboxylic acid salts (PCA) and sodium lactate, which is very hygroscopic. Many factors can influence the amount of water in the SC and the amount of NMF, as is clear from overuse of skin cleansers that remove the NMF. Excessive relative humidity of the environment and ultraviolet radiation interrupt proteolysis of filaggrin, reducing the formation of NMF. Ageing also reduces the formation of NMF (3). On the other hand, in the extracellular space of the dermis is hyaluronic acid with hydrophilic properties, forming a thick gel that prevents the flow of large quantities of fluids, contributing to deep dermal hydration (4).

For a long time, researchers have attempted to relate skin hydration with its biomechanical behaviour, including elasticity and viscoelasticity (5), considering the predictable interaction of water molecules and dermal collagen fibers, but not overlooking the hydration of SC. Several studies can be found in literature on this relationship. Hendricks et al took measurements in the arm with suction methods combined with optical coherence tomography in order to observe differences between the epidermis in hydrated and non-hydrated skin. He obtained disparate results between different volunteers, without finding any significant trend (7).

Another study aimed to determine the sensitivity of $\mathrm{Cu}$ tometer ${ }^{\circledR}$ MPA 580 descriptors in epidermal hydration, and to correlate the biomechanical properties and the capacitance measured with a Corneometer ${ }^{\circledR}$. Increased capacitance was observed, but a strong correlation was not found between this and the biomechanical properties of the skin. (8). However, this study identified the descriptors UV and UV / Ue as sensitive to moisture variations.

, Sandford et al aimed to observe the performance of a dynamic mechanical device (DMD) (9) in the change detection on the mechanical properties of the skin after its hydration by increasing the relative humidity in a chamber where the arm of the volunteers was contained during testing. These results suggest that these proper-

\section{Introdução}

O conteúdo hídrico do estrato córneo (SC) é crucial para a manutenção da elasticidade, força tênsil, integridade da barreira e resistência elétrica (1). Apesar da sua natureza lipofílica, o SC tem capacidade de reter água devido à existência de ligações compactas entre os corneócitos, às regiões lipídicas no espaço intercelular e ao fator humectante natural (NMF). Este último é obtido através da lise da filagrina (2) sendo uma mistura complexa de aminoácidos, ácidos orgânicos, ureia, e iões. A sua eficácia reside no facto de ser constituído maioritariamente por sais do ácido pirrolidinocarboxílico (PCA) e lactato de sódio, que são muito higroscópicos. Muitos fatores podem influenciar a quantidade de água no SC, e a quantidade de NMF, como resulta do uso exagerado de produtos de limpeza da pele que fazem com que os NMF sejam removidos. A excessiva humidade relativa do ambiente e a radiação ultravioleta, interrompem a proteólise da filagrina, produzindo menos formação de NMF. O envelhecimento também reduz a formação de NMF (3). Por outro lado, no espaço extracelular da derme existe ácido hialurónico, com propriedades hidrofílicas, que forma um gele espesso que impede o fluxo de grandes quantidades de fluidos, contribuindo para a hidratação cutânea profunda (4).

Há muito tempo que se procura relacionar a hidratação da pele com o seu comportamento biomecânico, incluindo a elasticidade e a viscoelasticidade (5), considerando a previsível interação das moléculas de água e as fibras de colagénio da derme, sem esquecer a hidratação do SC (6). Podem ser encontrados na literatura alguns estudos sobre esta relação. Hendricks realizou medições no braço com métodos de sucção combinados com tomografia ótica de coerência de forma a observar diferenças na epiderme entre a pele hidratada e não hidratada. Obteve resultados díspares entre os diferentes voluntários, não chegando a encontrar nenhuma tendência significativa (7).

Outro estudo teve como objetivo determinar a sensibilidade dos descritores do Cutometer ${ }^{\circledR}$ MPA 580 na hidratação epidérmica, e fazer a correlação entre as propriedades biomecânicas e a capacitância medida com o Corneometer ${ }^{\circledR}$. Observou aumento da capacitância, mas não foram encontradas fortes correlações entre esta e as propriedades biomecânicas da pele.(8). No entanto, este estudo apontou como descritores mais sensíveis a variações de hidratação Uv e Uv/Ue..

Por seu lado, Sandford teve como objetivo observar o desempenho de um dispositivo mecânico dinâmico (DMD) (9) na deteção de alterações na extensibilidade da pele após a sua hidratação pelo aumento da humida- 
ties increase linearly with increasing relative humidity of the chamber (9).

A comparative study of the ability of two instruments, SEM Cutometer ${ }^{\circledR}$ Reviscometer ${ }^{\circledR}$ RVM 474 and 600, was also conducted for detection of mechanical changes of the skin surface due to small differences in skin dryness. There were no significant differences in measured descriptors with Cutometer ${ }^{\circledR}$ ( $\mathrm{Ur} / \mathrm{Ue}$ and $\mathrm{Uv} / \mathrm{Ue}$ ). However, with the Reviscometer ${ }^{\circledR}$ RVM 600 apparatus the lowest RRT values were observed in non-hydrated skin, and the Reviscometer ${ }^{\circledR}$ was found to be the most sensitive device (10).

Thus, it becomes apparent that the SC hydration effect on the biomechanical behaviour of the skin in vivo is not completely understood.

A new system has recently been introduced on the market, the Cutiscan ${ }^{\circledR}$ CS 100 , using a new approach of measuring viscoelasticity and anisotropy, combining mechanical strength and imaging in a unique way.

This paper seeks to investigate the influence of hydration of human skin in its biomechanical behaviour, exploring these properties with various measurement systems including the new CutiScan ${ }^{\circledR}$ CS 100.

\section{Materials and methods}

12 volunteers participated in the study, healthy men and women aged between 18 and 25 years (mean $22.8 \pm 1.4$ years). Volunteers were selected after informed consent and all procedures were conducted according to the principles of the Declaration of Helsinki and respective amendments.

Some restrictions were imposed in order to limit external influences in the study:

1. Application of cosmetic products 48 hours prior to the study at baseline;

2. Use of tight clothing in the area to be analyzed;

3. Dermatological or pharmacological treatment that may interfere with measurements;

4. Intense sun exposure in the days prior to the study.

The biomechanical properties of the skin were evaluated with Reviscometer ${ }^{\circledR}$ RVM 600, Cutometer ${ }^{\circledR}$ MPA 580, and CutiScan ${ }^{\circledR}$ CS 100 (Courage-Khazaka Electronics $\mathrm{GmbH}$, Cologne, Germany) devices.

A preliminary study was performed to confirm the impact of the application of an occlusive patch saturated with water and glycerine for 24 hours, measuring de relativa dentro de uma camara onde estava o braço dos voluntários. Os seus resultados sugerem que estas propriedades aumentam linearmente com o aumento da humidade relativa da camara (9).

Foi feito também um estudo comparativo da capacidade de dois instrumentos, Cutometer ${ }^{\circledR}$ SEM 474 e Reviscometer® RVM 600, na detecção de alterações mecânicas da superfície da pele devido a pequenas diferenças na secura da pele. Não se observaram diferenças significativas nos descritores medidos com o aparelho Cutometer ${ }^{\circledR}$ SEM 474 (Ur/Ue e Uv/Ue). No entanto, com o aparelho Reviscometer ${ }^{\circledR}$ RVM 600 observaram-se valores mais baixos de RRT em pele não hidratada, tendo-se concluído que o aparelho Reviscometer® RVM 600 parece ser o mais sensível (10).

Assim, torna-se evidente que não é ainda completamente compreendido o efeito da hidratação do SC no comportamento biomecânico da pele in vivo.

Foi recentemente introduzido no mercado um novo sistema, o Cutiscan ${ }^{\circledR}$ CS 100, utilizando uma nova abordagem de medição da anisotropia e viscoelasticidade, combinando força mecânica e imagem de uma forma única.

O presente trabalho procura contribuir para investigar a influência da hidratação da pele humana no seu comportamento biomecânico, explorando estas propriedades com diversos sistemas de medição incluindo o novo CutiScan ${ }^{\circledR}$ CS 100.

\section{Materiais e métodos}

Participaram no estudo 12 voluntários, saudáveis, de ambos os sexos, com idades compreendidas entre os 18 e os 25 anos ( média $22,8 \pm 1,4$ anos). Os voluntários foram selecionados após consentimento informado e todos os procedimentos foram realizados segundo os princípios da Declaração de Helsínquia e respetivas emendas.

Foram impostas algumas restrições com a finalidade de limitar influências externas no estudo:

1. Aplicação de produtos cosméticos nas $48 \mathrm{~h}$ anteriores ao início do estudo;

2. Utilização de vestuário apertado na zona a analisar; 3. Tratamento dermatológico ou farmacológico que interfira com as medições;

4. Exposição solar intensa nos dias anteriores ao estudo. As propriedades biomecânicas da pele foram avaliadas com os aparelhos Reviscometer ${ }^{\circledR}$ RVM 600, Cutometer $^{\circledR}$ MPA 580 e CutiScan ${ }^{\circledR}$ CS 100 (Courage-Khazaka Electronics $\mathrm{GmbH}$, Colónia, Alemanha).

Foi realizado um estudo preliminar para confirmar o impacto da aplicação de um penso oclusivo saturado 
hydration in the SC with the Corneometer ${ }^{\circledR}$ CM 825 (Courage-Khazaka Electronics $\mathrm{GmbH}$, Cologne, Germany). As expected, there was obtained a significant increase in capacitance two hours after removal of the occlusive dressing with water and glycerine, leading to an increased skin hydration (Figure 1). From this assumption, the main study protocol was designed.

The study was conducted on the ventral forearm. After a rest period of 15 minutes and acclimatization, all measurements were performed under constant environmental conditions $\left(20-22^{\circ} \mathrm{C}\right.$ and relative humidity $40-60 \%$ ) with the volunteer sitting, with a $90^{\circ}$ angle between the upper arm and forearm. In order to ensure that the measurements were always carried out at the same site, the selected anatomical area was marked equidistant between the elbow and wrist area and equidistant between the left and right side of the forearm. All measured parameters for the study before application of the occlusive dressing described above and two hours after its removal were considered relevant. com água e glicerina, durante 24horas, na hidratação do SC medida através do Corneometer ${ }^{\circledR}$ CM 825 ( Courage-Khazaka Electronics $\mathrm{GmbH}$, Colónia, Alemanha). Tal como esperado, obteve-se um aumento significativo na capacitância $2 \mathrm{~h}$ após a remoção do penso oclusivo com água e glicerina, traduzindo-se num aumento da hidratação cutânea (Figura 1). A partir deste pressuposto, foi elaborado o protocolo do estudo principal.

O estudo foi realizado no antebraço ventral. Após um período de repouso e aclimatização de 15 minutos, todas as medições foram realizadas sob condições ambientais constantes $\left(20-22^{\circ} \mathrm{C}\right.$ e humidade relativa 40 $60 \%$ ), com o voluntário sentado, com um ângulo de $90^{\circ}$ entre o braço e o antebraço. De modo a garantir que as medições eram sempre realizadas no mesmo sítio dentro da área anatómica selecionada, foi marcada a zona equidistante entre cotovelo e pulso e a zona equidistante entre o lado direito e esquerdo do antebraço. Foram medidos todos parâmetros considerados relevantes para o estudo antes da aplicação do penso oclusivo descrito acima e $2 \mathrm{~h}$ após a sua remoção.

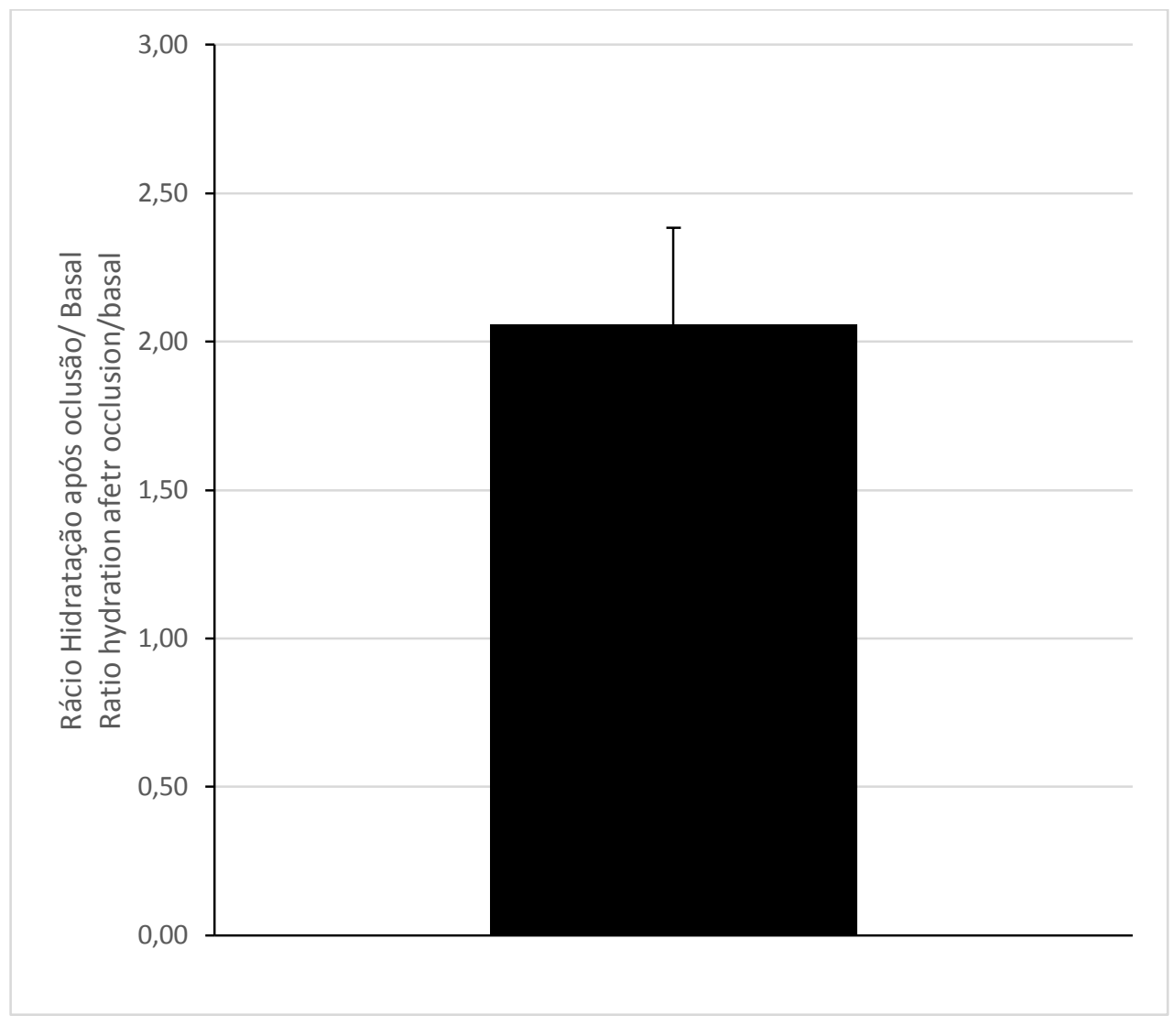

Figure 1/ Figure 1. Ratio of hydration values obtained after occlusion and baseline (mean $\pm \mathrm{SD}$ ) Rácio dos valores de hidratação obtidos após oclusão e os valores basais (média $\pm \mathrm{DP}$ ) 
The measurements performed with the Cutometer ${ }^{\circledR}$ MPA 580 had a suction cycle with a constant pressure of 400 mbar, held for approximately 3 seconds, followed by a relaxation period also of approximately 3 seconds. The following descriptors were measured:

- R0 or Uf which is the maximum amplitude and is the passive behavior of the skin to force (firmness), measured in $\mathrm{mm}$.

- R5 or Ur / Ue corresponding to the total elasticity (\%) - R6 or Uv / Ue corresponding to the viscoelastic reason, relation between elastic and viscoelastic extension $(\%)$.

- R8 or Ua which is the maximum relaxation after cessation of suction $\mathrm{mm}$.

For Reviscometer ${ }^{\circledR}$ RVM 600 device, the route resonance of an acoustic wave resonance running time (RRT) was analysed, obtained at $0^{\circ}, 45^{\circ}, 90^{\circ}$ and $135^{\circ}$ angles. This descriptor has an inverse relationship to the skin elasticity. Moreover, the positioning of the probe on the skin allowed measurements in various directions, permitting an assessment of skin anisotropy. In the CutiScan ${ }^{\circledR}$ CS 100 a "time / strain" measuring mode was also used, adjusted to a suction cycle with a constant pressure of 400 mbar, held for approximately 3 seconds, followed by a relaxation period also of approximately 3 seconds. The machine calculated the following descriptors for each $360^{\circ}$ angle:

- Maximum displacement during the suction time (V1), - After suction return rate (V2)

- The ratio between V1 and V2 (V3) calculated as a percentage

In this work, the data obtained were analysed at $0^{\circ}, 45^{\circ}$, $90^{\circ}$ and $135^{\circ}$ angle in order to compare against the results obtained with the Reviscometer.

The results were analyzed using the statistical 'software' SPSS 19 IBM (IBM, NY, USA). The nonparametric Wilcoxon test and a 0.05 significance level were used.

\section{Results}

After analyzing the results obtained with Cutometer ${ }^{\circledR}$ MPA 580, no noticeable change can be seen between the descriptors before and after occlusion (Figure 2, a-d).

In the Reviscometer ${ }^{\circledR}$ RVM 600 data, statistically significant differences can only be seen between results obtained before and after occlusion at a $135^{\circ}$ angle (Figure 3). However, at $0^{\circ}, 45^{\circ}$ and $90^{\circ}$ angles, there was always an increase in the RRT as hydration increased,
As medições realizadas com o Cutometer $^{\circledR}$ MPA 580 tiveram um ciclo de sucção com uma pressão constante de 400 mbar, mantida durante cerca de 3 segundos, seguida por um período de relaxamento também de cerca de 3 segundos. Foram medidos os descritores:

- R0 ou Uf que corresponde à amplitude máxima e representa o comportamento passivo da pele à força, medido em $\mathrm{mm}$.

- R5 ou Ur/Ue que corresponde à elasticidade total (\%) - R6 ou Uv/Ue que corresponde à razão viscoelástica, relação entre a extensão elástica e viscoelástica (\%).

- R8 ou Ua que corresponde ao relaxamento máximo após cessação da sucção mm.

Para o aparelho Reviscometer ${ }^{\circledR}$ RVM 600, foi analisado o percurso de ressonância de uma onda acústica, resonance running time (RRT), obtido nos ângulos $0^{\circ}, 45^{\circ}$, $90^{\circ}$ e $135^{\circ}$. Este descritor tem uma relação inversa com a elasticidade cutânea. Por outro lado, o posicionamento da sonda sobre a pele permite medições em várias direções, possibilitando uma avaliação da anisotropia cutânea.

No CutiScan ${ }^{\circledR}$ CS 100 também foi utilizado o modo de medição «time/strain», ajustado para um ciclo de sucção com uma pressão constante de 400 mbar, mantida durante cerca de 3 segundos, e seguida por um período de relaxamento também de cerca de 3 segundos. O equipamento calcula os seguintes descritores para cada ângulo em $360^{\circ}$ :

- deslocamento máximo durante o tempo de sucção (V1),

- taxa de retorno após sucção (V2)

- rácio entre V1 e V2 (V3), calculado em percentagem Neste trabalho, foram analisados os dados obtidos para os ângulos $0^{\circ}, 45^{\circ}, 90^{\circ}$ e 135 , por forma a fazer uma comparação com os resultados obtidos com o Reviscometer.

Os resultados foram analisados usando o «software» de estatística IBM SPSS Statistics 19 (IBM, Nova Iorque, EUA). Foi usado o teste não-paramétrico de Willcoxon e um nível de significância de 0,05 .

\section{Resultados}

Após análise dos resultados obtidos com o Cutometer ${ }^{\circledR}$ MPA 580, pode ser observado que não existem alterações assinaláveis entre os descritores antes e após a oclusão (Figura 2 a)-d)).

Nos dados do Reviscometer ${ }^{\circledR}$ RVM 600 pode observar-se que apenas existem diferenças estatisticamente significativas entre os resultados obtidos antes e após oclusão no ângulo $135^{\circ}$ (Figura 3). No entanto, nos ângulos $0^{\circ}, 45^{\circ} \mathrm{e} 90^{\circ}$, houve sempre um aumento 
but these differences did not reach significance. Evaluating the ratio between the maximum and minimum RRT as indicative of anisotropy results, we can observe a decrease thereof with increased hydration, although not statistically significant (Table 1). The same was observed when analyzing the average RRT before and after occlusion.

a)

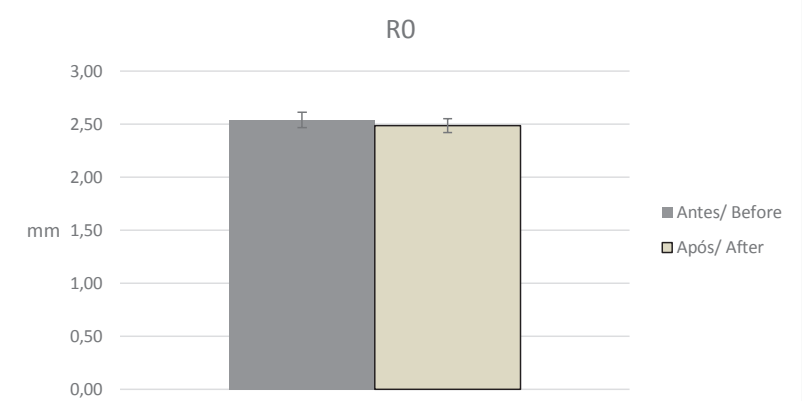

b)

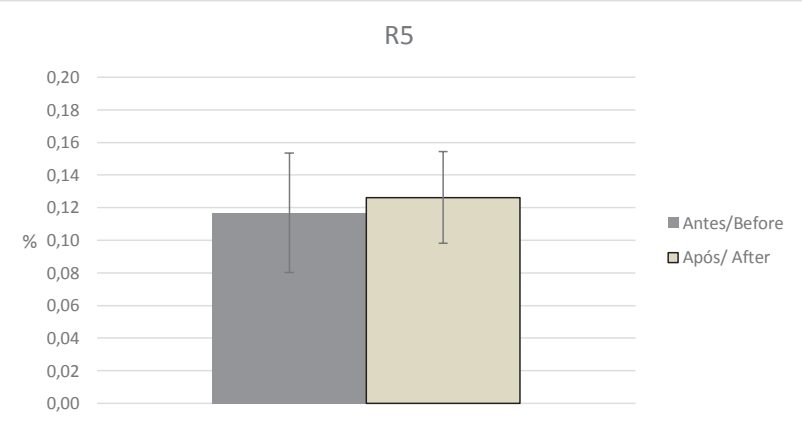

do RRT quando aumentou a hidratação, mas estas diferenças não atingiram a significância. Nos resultados indicativos da anisotropia, avaliados através do rácio entre o RRT máximo e o RRT mínimo, podemos observar uma diminuição deste com aumento da hidratação, embora não estatisticamente significativa (Tabela 1). O mesmo foi observado ao analisar-se o RRT médio antes e após oclusão.

c)

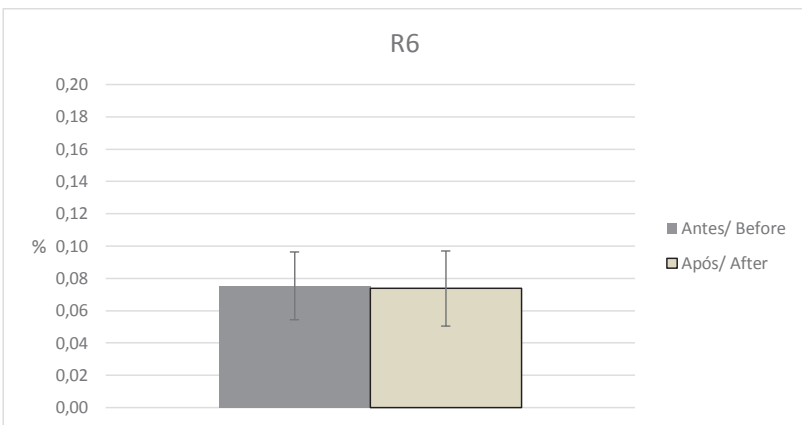

d)

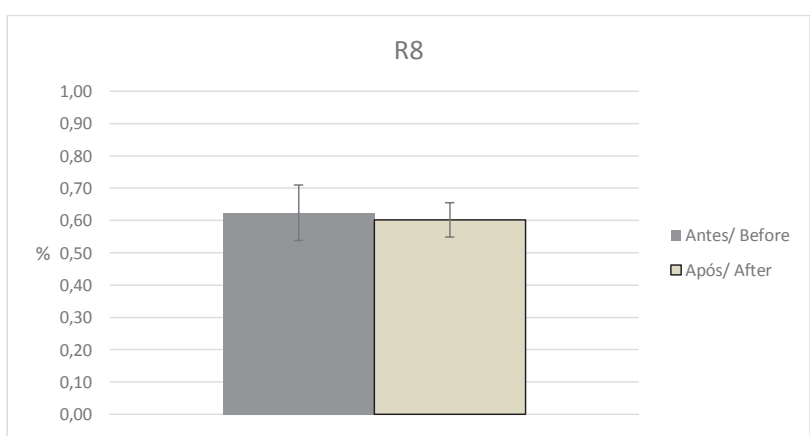

Figure 2 a) - d)/ Figura 2 a) - d). Parameters obtained with Cutometer ${ }^{\circledR}$ before and after occlusion (mean $\pm \mathrm{SD}$ )

Parâmetros obtidos com o Cutometer ${ }^{\circledR}$ antes e após oclusão (média \pm DP)

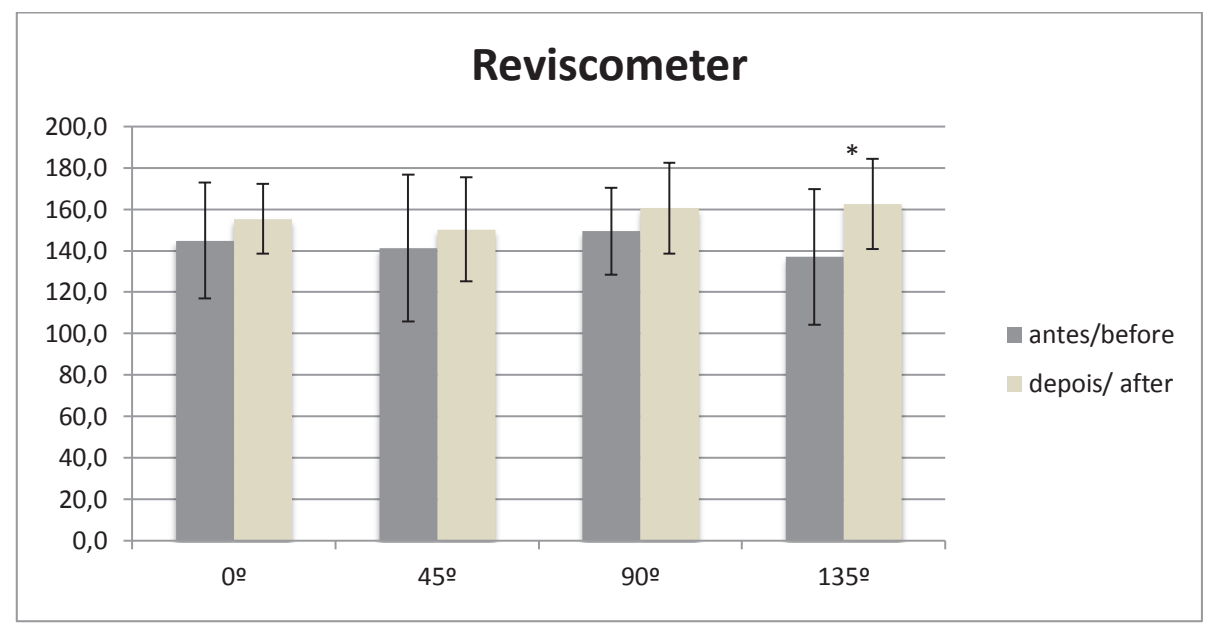

Figure 3/ Figura 3. Resonance running times (RRT) for angles $0^{\circ}, 45^{\circ}, 90^{\circ}$ and $135^{\circ}$ before and after occlusion (mean $\left.\pm \mathrm{SD}\right) * \mathrm{p}<0.05$

Resonance running times (RRT) para os ângulos $0^{\circ}, 45^{\circ}, 90^{\circ}$ e $135^{\circ}$ antes e após oclusão (média $\pm \mathrm{DP}) * \mathrm{p}<0,05$ 
Table 1/ Tabela 1. RRT and anisotropy observed with Reviscometer ${ }^{\circledR}$ RVM 600 unit RRTm e anisotropia observadas com o aparelho Reviscometer ${ }^{\circledR}$ RVM 600

\begin{tabular}{|c|c|c|c|}
\hline \multirow[t]{2}{*}{ RRT } & Mean/ Média & 143,4 & 157,2 \\
\hline & Standard deviation/ Desvio padrão & 5,27 & 5,54 \\
\hline \multirow{2}{*}{$\begin{array}{l}\text { Anisotropy/ } \\
\text { Anisotropia } \\
\text { (RRTmax/ RRTmin ) }\end{array}$} & Mean/ Média & 1,571 & 1,259 \\
\hline & Standard deviation/ Desvio padrão & 0,618 & 0,107 \\
\hline
\end{tabular}

For CutiScan ${ }^{\circledR}$ CS 100 , the descriptor V3 was little changed at $0^{\circ}, 45^{\circ}, 90^{\circ}$ and $135^{\circ}$ angles before and after the application of the occlusive dressing containing water and glycerin (Figure 4). No significant differences were observed.
Para o CutiScan ${ }^{\circledR}$ CS 100 , o descritor V3 nos ângulos $0^{\circ}, 45^{\circ}, 90^{\circ}$ e $135^{\circ}$ não sofreu grandes alterações antes e após a aplicação do penso oclusivo contendo água e glicerina (Figura 4), não tendo sido observadas diferenças significativas.

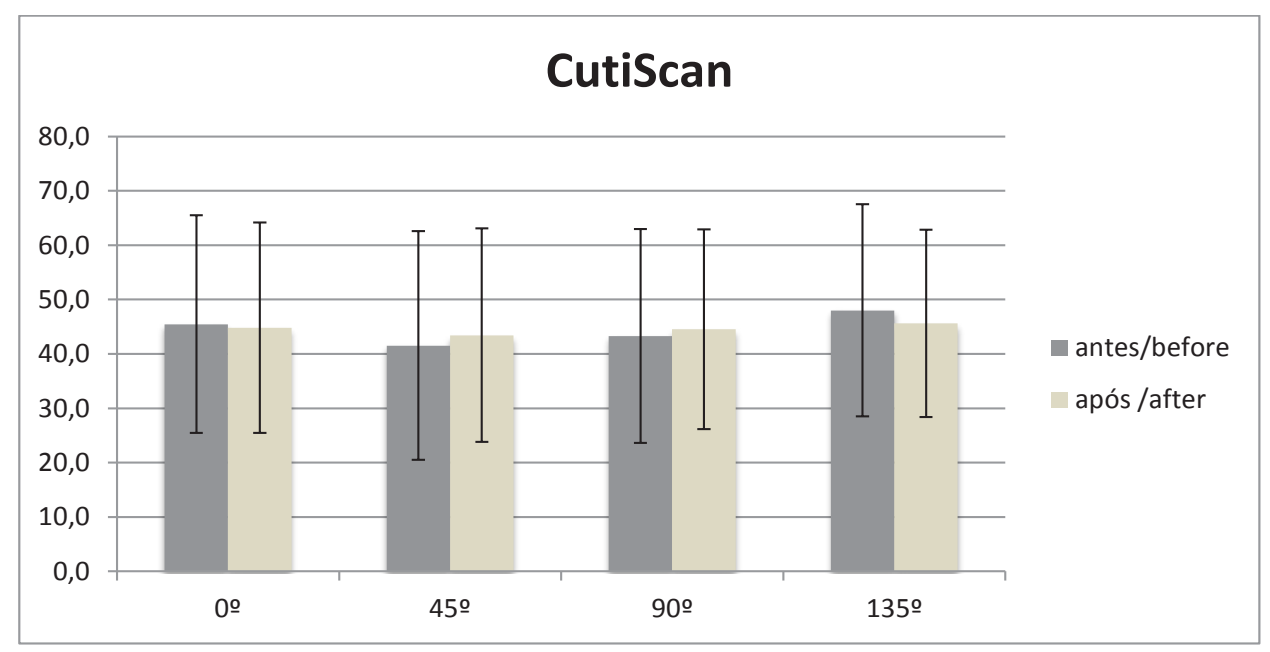

Figure 4/ Figura 4. V3 determined in angles $0^{\circ}, 45^{\circ}, 90^{\circ}$ and 135 before and after occlusion (mean \pm SD)

V3 determinado nos ângulos $0^{\circ}, 45^{\circ}, 90^{\circ}$ e $135^{\circ}$ antes e após oclusão (média $\pm \mathrm{DP})$ 


\section{Discussion}

Prolonged occlusion with a patch containing water and glycerine allows the skin to increase its water content, because glycerine is a hygroscopic substance and causes environmental moisture to be retained, so that the amount of water usually lost by evaporation to the surface of the skin is reduced. Moreover, occlusion prevents loss of water to the skin surface by diffusion, and makes more water available to bind to the glycerine, enabling an increase of SC hydration levels $(11,12)$. Moreover, occlusion increases the size of the corneocytes and promotes insertion of water in the intercellular lipid domains (12). For these reasons, it seemed that occlusion would be a good strategy to control the overhydration process of the epidermis on our volunteers.

The hypothesis that the hydration affects the mechanical behaviour of the skin has been addressed in various papers, but. although widely accepted, has not been clearly experimentally demonstrated.

In our experimental conditions, we observed differences in the descriptors provided by Cutometer ${ }^{\circledR}$. Uf, the maximum amplitude of skin strain after suction, is representative of passive opposition to the tissue application and is related to strength and extensibility. The Uf results in our work are not in agreement with the study of Sandford et al, wherein the extensibility of the skin increased with hydration (9). However, other authors state that skin extensibility increases as water content decreases (10). We observed statistically significant changes in Ua before and after occlusion, however, the value of the maximum relaxation after cessation of suction declined slightly, reflecting a decreased ability of the skin to return to its original state. Also, for $\mathrm{Ur} / \mathrm{Ue}$ and Uv / Ue, the changes were observed with increasing hydration were not very significant. However, these results suggest that after occlusion the total elasticity increases and the viscoelastic ratio decreases, indicating an increase of the elastic properties of the skin. A decrease in Uv / Ue can be indicative of a decrease in viscosity of dermal interstitial fluid as a result of increased water and changes the composition of proteoglycans (13). In addition, water accumulating in the dermis decreases the friction between the fibres and facilitates movement of the interstitial fluid, making the skin more elastic (13). According to these authors, the Ur / Ue parameters, Uv / Ue are very correlated with age and depend essentially on dermal components. The results for the parameter $\mathrm{Uv} / \mathrm{Ue}$ obtained in this study do not support the hypothesis formulated by Dobrev, who claims that this is one of the most sensitive parameters to hydration (8).

\section{Discussão}

A oclusão prolongada com um penso contendo água e glicerina permite que a pele aumente o seu conteúdo hídrico, pois a glicerina é uma substância higroscópica e faz com que a humidade ambiental seja retida e que a quantidade de água normalmente perdida por evaporação à superficie da pele seja menor. Além disso, a oclusão impede a perda de água para a superfície cutânea por difusão, bem como faz com que mais água esteja disponível para se ligar à glicerina e seja possível aumentar os níveis de hidratação do SC $(11,12)$. Por outro lado, a oclusão aumenta o tamanho dos corneócitos e promove a inserção de zonas com água nos domínios lipídicos intercelulares (12). Por estas razões, pareceu-nos que a oclusão seria uma boa estratégia para controlar o processo de sobrehidratação da epiderme nos nossos voluntários.

A hipótese de que a hidratação influencia o comportamento mecânico da pele foi abordada em vários trabalhos, mas apesar de amplamente aceite, não foi ainda claramente demonstrada.

Nas nossas condições experimentais, não observámos diferenças nos descritores proporcionados pelo Cutometer $^{\circledR}$. Uf, a amplitude máxima de distensão da pele após sucção, é representativa da oposição passiva dos tecidos à aplicação de força. Os resultados de Uf do nosso trabalho não estão de acordo com o estudo de Sandford, em que a extensibilidade da pele aumentou com a hidratação (9). No entanto, outros autores afirmam que, pelo contrário, a Uf da pele aumenta à medida que o seu conteúdo de água diminui (10). Não observámos alterações estatisticamente significativas de Ua antes e após oclusão, no entanto, o valor do relaxamento máximo após cessação da sucção diminuiu ligeiramente, traduzindo uma menor capacidade da pele regressar ao seu estado original. Também para os parâmetros Ur/Ue , Uv/Ue não se observaram alterações muito significativas com o aumento da hidratação. No entanto, estas sugerem que, após a oclusão, a elasticidade total aumenta e a razão viscoelástica diminui, indicando um aumento das características elásticas da pele. Uma diminuição de Uv/Ue pode ser indicativa de uma diminuição na viscosidade do fluido intersticial dérmico, como resultado do aumento da água e mudanças na composição dos proteoglicanos (13). Além disso, a acumulação de água na derme diminui a fricção entre as fibras e facilita o movimento do fluido intersticial, tornando a pele mais elástica (13). Segundo estes autores, os parâmetros Ur/ Ue, Uv/Ue são muito correlacionados com a idade e dependem essencialmente dos componentes dérmicos. Os resultados obtidos no presente trabalho no parâme- 
The RRT is directly proportional to the speed with which the wave propagates on the surface of the skin and depends on the intensity and exposure of skin tension lines. An increase in the RRT is usually indicative of a higher tension in the dermis and therefore a deterioration in the elastic properties of the skin. After analysing the results obtained in the multidirectional study i.e., RRT of various angles, such an increase can be observed after occlusion. This finding confirms the results observed by Paye et al, indicating that lower RRT values are found on non-hydrated skin (10), i.e. SC hydration is revealed by increasing the RRT. On the other hand, the anisotropy results show a significant decrease with increased hydration, suggesting more uniform skin characteristics in all directions. However, it should be kept in mind that this equipment is influenced by many factors such as skin temperature, pressure applied to the probe during the measurement and the relation between emission and detection of the sensors (14).

The CS CutiScan $100 \AA$, like the Reviscometer, is intended to measure the skin viscoelasticity and anisotropy. Its probe combines mechanical strength with imaging having a suction ring which displaces the skin uniformly in all directions by means of negative pressure. During the time of suction and recovery, a highresolution camera located inside the probe monitors the displacement of each pixel of an optical flow algorithm, generating a video through which a $360^{\circ}$ graph is generated, and descriptors are calculated. The data indicates that there is some analogy between V1 and Uf, and V2 and Ua.

With Cutiscan ${ }^{\circledR}$ CS 100 , practically no differences were observed in the viscoelastic behaviour before and after occlusion. It should be noted also that the standard deviations for each descriptor and for each angle were greater than those obtained with the other equipment used in this study. These results can be explained by the fact that this machine is far more complex in its operation and more prone to variability with the operator, as has been already reported in previous studies (15).

Making a comparative analysis of the data obtained in this work with three devices, only the Reviscometer permitted the observation of significant differences attributable to skin overhydration. A general trend of improvement of the biomechanical properties of the skin with increased hydration could also be noted.

The discrepancy between the findings obtained in this study and other studies can be attributed to different factors, including:

1. The use of equipment with very different measuring principles (Reviscometer vs Cutometer and CutiScan);

2. Different probe aperture diameters $(14 \mathrm{~mm}$ CutiScan vs $2 \mathrm{~mm}$ Cutometer); tro Uv/Ue, não corroboram a hipótese formulada por Dobrev, que afirma que este é um dos parametros mais sensiveis à hidratação (8).

O RRT é diretamente proporcional à velocidade com que a onda se propaga na superfície da pele e depende da intensidade e orientação das linhas de tensão da pele. Um aumento do RRT é normalmente indicativo de uma maior tensão na derme e, por isso, de um agravamento nas características elásticas da pele. Após análise dos resultados obtidos no estudo multidirecional, isto é, do RRT dos vários ângulos podemos observar um aumento deste, após a oclusão. Este dado corrobora os resultados observados por Paye, que indica que valores mais baixos de RRT são encontrados em pele não hidratada (10) ou seja, a hidratação do SC, favorecendo a pele, revela-se por aumento do RRT. Por outro lado, os resultados da anisotropia mostram uma diminuição significativa com aumento da hidratação, sugerindo uma maior uniformidade das características da pele, em todas as direções. No entanto, deve ter-se em conta que este equipamento é influenciado por muitos fatores, como a temperatura da pele, pressão aplicada na sonda aquando da medição e a relação entre emissão e detecção entre os sensores (14).

O CutiScan CS $100^{\circledR}$, tal como o Reviscometer, destina-se a medir a viscoelasticidade e anisotropia cutâneas. A sua sonda combina força mecânica com imagem de forma única, possuindo um anel de sucção que desloca a pele uniformemente em todas as direcções, através de pressão negativa. Durante o tempo de sucção e recuperação, uma câmara de alta resolução localizada no interior da sonda monitoriza o deslocamento de cada pixel por um algoritmo de fluxo óptico, gerando um vídeo através do qual um gráfico em $360^{\circ}$ é gerado, bem como são calculados descritores. Pode ser considerado que existe alguma analogia entre V1 e Uf, V2 e Ua.

Com o Cutiscan ${ }^{\circledR} \mathrm{CS} 100$, praticamente não foram observadas diferenças no comportamento viscoelástico antes e após oclusão. Nota-se também que os desvios padrão em cada descritor e para cada ângulo são maiores do que os obtidos com os outros equipamentos usados neste estudo. Estes resultados podem ser explicados pelo facto de este equipamento ser bastante mais complexo na sua operação e mais susceptível a variabilidade com o operador, o que já foi reportado em estudos anteriores (15).

Fazendo uma análise comparativa dos dados obtidos neste trabalho com os três aparelhos, verificou-se, logo à partida, que apenas o Reviscometer permitiu observar diferenças significativas atribuíveis à sobrehidratação cutânea. Também é possível notar uma tendência geral de melhoria das propriedades biomecânicas da pele com aumento da hidratação. 
3. Different hydration levels achieved in healthy volunteers (overhydration occlusion vs hydration increase in a chamber);

4. Different anatomical zones (forearm vs. face);

5. Heterogeneity between the age of the volunteers (young adult panel vs panel with comprehensive range of age)

\section{Conclusion}

The results of this study corroborate the existence of relationship between the hydration of the SC and the biomechanical properties of the skin in vivo. However, it was noted that the establishment of this relationship depends directly on the technology used in the measurement, and it was not possible to fully clarify all the variables that can be decisive in the interpretation of data. Therefore, complementing this study with further work is recommended so that this research question can be better understood by increasing the sample size as well as the breadth of the range of ages of the volunteers.

\section{Conflict of interest}

The authors declare that there are no financial and/or personal relationships that could be viewed as presenting a potential conflict of interest.
A discrepância entre as conclusões obtidas neste trabalho e em outros estudos pode ser atribuída a diferentes factores, como sejam:

1. O uso de equipamentos com princípios de medição bastante diferentes (Reviscometer vs Cutometer e CutiScan);

2. Diferentes diâmetros de abertura de sonda $(14 \mathrm{~mm}$ CutiScan vs $2 \mathrm{~mm}$ Cutometer);

3. Diferentes níveis de hidratação atingidos nos voluntários (sobrehidratação por oclusão vs aumento de hidratação no interior de uma câmara);

4. Zonas anatómicas distintas (antebraço vs face);

5. Heterogeneidade entre a idade dos voluntários (painel de adultos jovens vs painel com gama de idade abrangente)

\section{Conclusão}

Os resultados obtidos neste estudo corroboram a existência de relação entre a hidratação do SC e as propriedades biomecânicas da pele in vivo. No entanto, foi observado que o estabelecimento dessa relação depende diretamente da tecnologia utilizada na medição, não tendo sido possível esclarecer inteiramente todas as variáveis que podem ser determinantes. Assim, recomenda-se a execução de estudo complementar para que esta questão de investigação possa ser melhor compreendida, aumentando a amostra, bem como a amplitude da gama de idades dos voluntários:-

\section{Conflito de interesses}

Os autores declaram a inexistência de qualquer tipo de relação financeira ou pessoal que possa representar um potencial conflito de interesses. 


\section{References/ Referências}

(1) Leyden J J, Rawlings AV. Skin Moisturization. London: CRC Press;2002

(2) Kadunc B, Palermo E, Addor F, Metsavaht L, Rabello L, Mattos R, Martins S. Tratado de cirurgia dermatologica, cosmiatria e laser. Rio de Janeiro: Elsevier Editora; 2013

(3) Verdier-Sévrain S, Bonté F. (2007). Skin hydration: A review on its molecular mechanisms. J Cosmet Dermatol 2007; 6(2): 7582.

(4) Clancy NT, Nilsson GE, Anderson CD, Leahy MJ. A new device for assessing changes in skin viscoelasticity using indentation and optical measurement. Skin Res Technol 2010;16(2):210-228

(5) $\mathrm{Xu} \mathrm{F}, \mathrm{Lu} \mathrm{TJ}$. Introduction to Skin Biothermomechanics and Thermal Pain. Heidelberg: Springer ; 2011

(6) Marks R, Payne PA. Bioengineering and the Skin. Heidelberg: Springer Science \& Business Media; 1981

(7) Hendriks FM, Brokken D, Oomens CWJ, Baaijens FPT. Influence of hydration and experimental length scale on the mechanical response of human skin in vivo, using optical coherence tomography. Skin Res Technol 2004; 10(4): 231-241
(8) Dobrev H. Cutometer and epidermal hydration. Skin Res Technol 2000;6:239-244

(9) Sandford E, Chen Y, Hunter I, Hillebrand G, Jones L. Capturing skin properties from dynamic mechanical analyses. Skin Res Technol 2013;19(1):339-349.

(10) Paye M, Mac-Mary S, Elkhyat A, Tarrit C, Mermet P, Humbert PH. Use of the Reviscometer for measuring cosmetics-induced skin surface effects. Skin Res Technol 2007; 13(4):343-349

(11) Fluhr JW, Gloor M, Lehmann L, Lazzerini S, Distante F, Berardesca E. (1999). Glycerol accelerates recovery of barrier function in vivo. Acta Dermato-Venereologica, 1999;79(6): 418-421

(12) Wilhelm KP, Zhai H, Maibach HI. Dermatotoxicology 7th ed. Boston: CRC Press; 2007
(13) Mahmood T, Akhtar N, Khan BA, Shoaib Khan HM, Saeed T. (2010). Changes in skin mechanical properties after long-term application of cream containing green tea extract. Aging Clinical and Experimental Research, 2010; 23(5-6):333-336

(14)Hermanns-Lê T, Jonlet F, Scheen A, Piérard GE. (2001). Age- and body mass index-related changes in cutaneous shear wave velocity. Exp Gerontology 2001;36(2): 363-372

(15) Rosado C, Antunes F, Barbosa R, Fernando

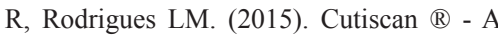
new system of biomechanical evaluation of the skin in vivo - comparative study of use depending on the anatomical site. Biomed Biopharm Res 2015; 12(1):49-57. 